\title{
Aktivitas Antibakteri Kombinasi Ekstrak Etanolik Daun Beluntas (Pluchaea indica Less.) dan Meniran (Phyllanthus niruri L.) terhadap Bakteri Staphylococcus aureus
}

\author{
Antibacterial Activity Combination ff Ethanolic Ekstract Beluntas Leaf (Pluchaea indica Less.) and \\ Meniran (Phyllanthus niruri L.) Againts Staphylococcus aureus.
}

Bella Agil Agustin, Nony Puspawaty, Rizal Maarif Rukmana*

Program Studi D-IV Analis Kesehatan Fakultas Ilmu Kesehatan, Universitas Setia Budi Surakarta

*Corresponding author: rizal.nerazuri@gmail.com

\begin{abstract}
ABSTRAK
Beluntas dan Meniran merupakan tanaman obat tradisional yang mengandung senyawa alkaloid, flavonoid, tannin, saponin, dan triterpenoid. Tujuan dari penelitian ini adalah untuk mengetahui adanya aktivitas antibakteri ekstrak etanolik daun Beluntas dan Meniran terhadap bakteri Staphylococcus aureus.

Metode ekstraksi yang digunakan dalam penelitian ini maserasi dengan etanol 96\%. Isolasi dan identifikasi bakteri Staphylococcus aureus dengan media VJA (Vogel Johnson Agar), pengecatan gram, uji katalase, dan uji katalase. Pengujian aktivitas antibakteri menggunakan metode difusi.

Hasil penelitian menunjukkan bahwa ekstrak etanolik daun Beluntas dan Meniran memiliki aktivitas antibakteri terhadap Staphylococcus aureus. Ekstrak etanolik daun Beluntas dan Meniran pada perbandingan 1:0, 2:1,1:1,1:2, dan $0: 1$ dengan konsentrasi 50\% terhadap bakteri Staphylococcusaureus dari rumah sakit adalah 10,67 mm, $13 \mathrm{~mm}, 17$ mm, $17 \mathrm{~mm}$, dan $20 \mathrm{~mm}$. Ekstrak etanolik daunBeluntas dan Meniran pada perbandingan 1:0, 2:1,1:1,1:2, dan $0: 1$ terhadap bakteri Staphylococcusaureus kultur laboratorium adalah $11 \mathrm{~mm}, 13,67 \mathrm{~mm}, 14 \mathrm{~mm}, 16,67 \mathrm{~mm}$, dan $18 \mathrm{~mm}$. Ekstrak etanolikdaun Beluntas dan Meniran dengan perbandingan $0: 1$ merupakan ekstrak yang memiliki zona hambat paling luas terhadap bakteri Staphylococcus aureus dari rumah sakit dan kultur laboratorium.
\end{abstract}

Kata kunci: Antibakteri, Ekstrak etanolik daun Beluntas dan Meniran, Staphylococcus aureus

\section{ABSTRACT}

Beluntas and Meniran a traditional medicinal plants compounds containing an alkaloid, flavonoid, tannin, saponin, and triterpenoid. The purpose of this study is to find the antibacterial activity extract etanolik leaves Beluntas and leaves Meniran of bacteria Staphylococcus aureus.

A method of extraction who used in this research maceration using ethanol $96 \%$. Isolation and identification bacteria Staphylococcus aureus to the media VJA (Vogel Johnson Agar), painting grams, test catalase and test coagulase. Testing methods have antibacterial activity diffusion.

The research results show that etanolic extracts of Beluntas and Meniran leaves having antibacterial activity of Staphylococcus aureus. Extract etanolik leaves Beluntas and leaves Meniran from the comparison 1: 0, 2: 1, 1:1, 1:2, and 0: 1 by concentration of the 50\% against bacteria Staphylococcusaureus from the hospital were 10,67 mm, $13 \mathrm{~mm}$, $17 \mathrm{~mm}, 17 \mathrm{~mm}$, and $20 \mathrm{~mm}$. Etanolic extract of Beluntas and Meniran leaves from the comparison 1: 0, 2: 1, 1:1, 1:2, and 0: 1 against bacteria Staphylococcus aureus laboratory culture respectively is $11 \mathrm{~mm}, 13,67 \mathrm{~mm}, 14 \mathrm{~mm}, 16.67 \mathrm{~mm}$, and $18 \mathrm{~mm}$. Etanolic extract of Beluntas and Meniran leaves by comparison 0: 1 is extract having a zone obstruent the most extensive against bacteria Staphylococcus aureus from hospital and the culture laboratory.

Keywords: Antibacterial, Etanolic extract of Beluntas and Meniran leaves, Staphylococcus aureus

\section{PENDAHULUAN}

Indonesia merupakan negara yang mempunyai iklim tropis dan lembab. Salah satu penyakit yang paling sering diderita oleh masyarakat di Indonsia adalah penyakit infeksi. Penyakit infeksi merupakan penyakit yang disebabkan oleh bakteri, virus, jamur, dan mikrobia lainnya (Muhaimin et al., 2003). Berdasarkan penelitian yang dilakukan oleh Badan Kesehatan Dunia (WHO) penyakit infeksi kulit di Indonesia mencapai 9,8\%. Penyakit infeksi pada kulit di sebabkan oleh beberapa macam bakteri, salah 
satunya adalah bakteri Staphylococcus aureus (Green, 2005).

Staphylococcus aureus merupakan bakteri flora normal pada kulit, hidung, tenggorokan, dan saluran pencernaan manusia. Staphylococcus aureus merupakan bakteri Grampositif, berbentuk bulat (coccus) dengan susunan bergerombol seperti anggur. Bakteri ini dapat ditemukan di tanah, udara, air, susu, makanan dan di lingkungan sekitar (Jawetz et al., 2001). Infeksi yang disebabkan oleh Staphylococcusaureus ditandai dengan kerusakan jaringan yang disertai abses bernanah (Moeloek, 2005).

Menurut Green (2005) banyak tanaman obat yang telah digunakan untuk menyembuhkan infeksi-infeksi yang disebabkan oleh bakteri yang sekarang telah resisten. Berdasarkan WHO ditemukan banyak tanaman obat yang memiliki khasiat antibakteri yang kuat, dan beberapa tanaman obat tersebut memiliki kemampuan yang lebih kuat dibandingkan antibiotik. Beberapa contoh tanaman obat tersebut adalah tanaman Beluntas dan Meniran.

Tanaman Beluntas (Pluchaea indica Less.) merupakan salah satu tanaman dari suku Asteraceae yang mengandung alkaloid, flavonoid, tanin, asam klorogenik, natrium, kalium, magnesium, dan fosfor (Agoes, 2010). Daun Beluntas (Pluchaea indica Less.) memiliki sifat antibakteri dan khasiat daun Beluntas ini diduga diperoleh dari kandungan senyawa yang berada di dalamnya (Dalimartha, 1999).

Tanaman Meniran (Phyllantus nirui L.) merupakan salah satu tanaman dari famili Euphorbiaceae yang tumbuh liar di tempat lembab dan berbatu, seperti semak-semak dan tanah diantara rerumputan (Djauhari dan Hermani, 2004). Meniran mengandung berbagai senyawa kimia antara lain alkaloid, lignin, triterpenoid, flavonoid (quersetin, quersitrin, isoquersitrin, astragalin, rutin, kaemferol-4, rhamnopynoside), asam lemak (asam ricinoleat, asam linoleate, asam linolenat), vitamin c, kalium, damar, tannin, geranin, saponin (Permadi,
2006). Berdasarkan kandungan dari senyawa kimia yang ada pada Meniran tersebut, Meniran dapat digunakan sebagai antibakteri. Berdasarkan penelitian yang telah dilakukan oleh Candrasari (2012) ekstrak etil asetat Meniran pada konsentrasi 20\% dapat menghambat bakteri Staphylococcus aureus.

Berdasarkan uraian di atas maka perlu dilakukan penelitian tentang aktivitas antibakteri kombinasi ekstrak etanolik Meniran dan Meniran terhadap bakteri Staphylococcus aureus.

\section{METODE PENELITIAN}

\section{Alat}

Alat yang digunakan untuk penelitian ini adalah: nampan, kain, blender, ayakan 40 mesh, baker glass, evaporator, oven, neraca analitik, cawan petri steril, kapas lidi steril, pipet ukur steril, api spiritus, inkas, tabung reaksi steril, jarum ose, mikroskop, inkubator, autoklave, kompor, botol sampel steril, paper disk, boorproof, mistar, alat pelindung diri lengkap.

Bahan-bahan lain yang digunakan seperti: Spiritus, cat Gram (Kristal violet, iodium, alkohol-aseton, dan safranin), minyak imersi, aquades, etanol, larutan $\mathrm{H} 2 \mathrm{O} 23 \%$, larutan plasma citrate, Ciprofloxacin.

\section{Prosedur Penelitian}

\section{Pembuatan Serbuk Daun Beluntas dan} Meniran.

Tiga kilogram daun Beluntas dan Meniran dicuci bersih supaya bersih dari kotoran debu kemudian dikeringkan dengan menggunakan oven hingga kering. Daun yang sudah kering kemudian dihaluskan dan kemudian diayak dengan mesh 40 .

\section{Penentuan Nilai Kadar Air Serbuk Daun Beluntas Dan Meniran}

Penentuan kadar air daun Beluntas dan Meniran masing-masing ditimbang 20 gram dan dimasukkan dalama labu alas bulat kemudian ditambah xylen $150 \mathrm{ml}$. Dipasang alat Bidwell 
Sterling dan dipanaskan dengan api kecil, pemanasan dihentikan apabila sudah tidak ada air yang menetes lagi pada tabung skala receiver.

\section{Identifikasi Golongan Senyawa}

a) Saponin

Dua $\mathrm{ml}$ ekstrak ditambah $10 \mathrm{ml}$ aquadest panas dalam tabung reaksi, dikocok kuat-kuat selama 10 detik, kemudian ditambah beberapa tetes $\mathrm{HCl} 2 \mathrm{~N}$. hasil positif jika terbentuk busa stabil (Setyawati et al., 2014).

b) Flavonoid

Dua $\mathrm{ml}$ ekstrak ditambah $2 \mathrm{ml}$ etanol 95\%, 0,05 gramserbuk seng dan $2 \mathrm{ml} \mathrm{HCl} 2 \mathrm{~N}$. larutan didiamkan selama 1 menit dan kemudian ditambah $2 \mathrm{ml} \mathrm{HCl}$ pekat. Hasil positif jika terbentuk warna merah jingga atau kuning (Rumanggit et al., 2015).

c) Tanin

Dua $\mathrm{ml}$ ekstrak ditambah $2 \mathrm{ml}$ air dan kemudian ditambah beberapa tetes $\mathrm{FeCl} 3$ 1\%. Hasil positif jika terbentuk larutan berwarna biru kehitaman (Sastrawan et al., 2013).

d) Triterpenoid

Uji triterpenoid menggunakan metode Lieberman-Burchard (LB). Dua mg ekstrak kering dilarutkan di anhidrat asetat, dipanaskan sampai mendidih, didinginkan dan kemudian 1 $\mathrm{ml} \mathrm{H} 2 \mathrm{SO} 4$ pekat ditambahkan di tabung reaksi, jika terbentuk warna atau ungu maka terdapat kandungan triterpenoid (Balafif et al., 2013).

e) Alkaloid

Empat $\mathrm{ml}$ ekstrak ditambah $0,5 \mathrm{ml} \mathrm{HCl}$, kemudian dibagi menjadi dua tabung. Tabung 1 ditambah reagen dragendrof dan tabung 2 ditambah 2-3 tetes reagen mayer. Positif jika tabung 1 terdapat endapan jingga dan tabung 2 terdapat endapan kekuningan (Ningsih etal.,

\section{Pembuatan Ekstrak Etanolik Daun Beluntas dan Meniran metode maserasi}

Beluntas dan Meniran dibuat perbandingan
$1: 0,2: 1,1: 1,1: 2$, dan $0: 1$. Serbuk daun Beluntas dan Meniran tersebut dimasukkan dalam botol maserasi, ditambahkan dengan pelarut etanol 96\% dengan perbandingan 1:10 (100 gram serbuk +1 liter pelarut). Maserasi dilakukan kurang lebih dua hari dan sesekali digojok. Setelah dua hari hasil maserasi disaring dengan kertas saring sehingga didapat filtrat

\section{Isolasi Bakteri}

Sampel digoreskan pada media VJA (Vogel Johnson Agar) menggunakan jarum ose lalu dinkubakasi pada suhu $37^{\circ} \mathrm{C}$ selama 24 jam. Hasil isolasi pada media VJA (VogelJohnson Agar) menunjukkan hasil positifadanya bakteri Staphylococcus aureus ditandai dengan koloni berwarna hitam, permukaan cembung, dan di sekitar koloni terbentuk warna kuning.

\section{Identifikasi Bakteri}

a) Pengececatan Gram: (1) Dibuat olesan tipis suspensi dari koloni murni bakteri pada objek glass yang bersih, dikering-anginkan. Setelah kering difiksasi dengan cara melewatkan bagian bawah objek glass di atas api bunsen (2) Olesan bakteri digenangi dengan cat Gram A (Kristal Violet) selama 1 menit (3) Dibilas dengan air mengalir beberapa detik kemudian dikeringanginkan (4) Olesan bakteri digenangi dengan cat Gram B (iodium) sebanyak 3 tetes didiamkan selama 1 menit (5) Dibilas dengan air mengalir beberapa detik kemudian dikering-anginkan (6) Ditambahkan cat Gram C (alkohol-aseton) untuk melunturkan sampai lapisan berwarna pucat kurang lebih selama 30 menit (7) Dibilas dengan air mengalir beberapa detik kemudian dikering-anginkan (8) Diteteskan cat Gram D (Safranin) dan dibiarkan selama 2 menit, kemudian dicuci dengan air mengalir lalu di keringanginkan (9) Bagian bawah objek glass dikeringkan dengan tissue, kemudian diamati di bawah mikroskop dengan perbesaran 100x10 kali menggunakan minyak emersi. Hasil positif jika sel berwana ungu berbentuk bulat dengan 
susunan bergerombol seperti anggur.

b) Uji Katalase

Koloni yang tumbuh berwarna hitam pada media VJA diuji katalase dengan $\mathrm{H} 2 \mathrm{O} 2$ 3\% yang diteteskan pada object glass kemudian diambil 1 ose koloni. Hasil positif ditandai dengan terbentukknya gelembung

c) Uji Koagulase

Koloni yang di tanam pada media BHI diuji koagulase dengan ditambahkan $1 \mathrm{ml}$ larutan plasma citrat ditambah $1 \mathrm{ml}$ suspensi bakteri kemudian diinkubasi pada suhu $37^{\circ} \mathrm{C}$ selama 18-24 jam. Hasil positif jika terbentuk gumpalan.

\section{Pembuatan Suspensi Bakteri}

Biakan bakteri Staphylococcus aureus diinokulasikan pada media BHI. Kekeruhan disetarakan dengan Standart Mc. Farland 1,5x103 cfu/ml (1,5 ml Barium Klorida dalam 8,5 Asam Sulfat).

\section{Uji Sensitivitas}

(1) Media Mueller Hinton Agar steril dituang ke dalam cawan petri dengan ketebalan $\pm 0,5 \mathrm{~cm}$ dibiarkan memadat pada suhu kamar (2) Kapas lidi steril dicelupkan pada suspensi bakteri uji lalu diinokulasikan secara merata pada media Mueller Hinton Agar (MHA) yang telah memadat. Ditunggu beberapa menit sampai kering, (3) Disk yang telah direndam selama 24 jam pada ekstrak di letakkan di atas media Mueller Hinton Agar (MHA), kontrol positif antibiotik Ciprofloxacin dan kontrol negatif Dimetilsulfoksida (DMSO 2\%) (4) Diinkubasi pada suhu $37^{\circ} \mathrm{C}$ selama 24 jam dan perlakuantersebut dilakukan 3 kali pengulangan 4) setelah Perubahan warna yang terjadi pada media disebabkan oleh asam yang dihasilkan pada metabolisme bakteri atau akibat kemampuan Staphylococcus aureus untuk memfermentasi manitol itu diukur zona jernih yang terbentuk disekitar paper disk.

Tabel 1. Hasil Penentuan Kadar Air Serbuk Daun Beluntas dan Meniran

\begin{tabular}{|l|l|}
\hline Tanaman & Kadar Air (\%) \\
\hline Beluntas & 9,9 \\
\hline Meniran & 7,5 \\
\hline
\end{tabular}

Tabel 2. Hasil Identifikasi Golongan Senyawa

\begin{tabular}{|l|l|}
\hline Kandungan & Belunt \\
\hline Alkaloid & + \\
\hline Flavonoid & + \\
\hline Tanin & + \\
\hline Saponin & + \\
\hline Triterpenoid & - \\
\hline
\end{tabular}

Gambar 1. (a) Koloni Staphylococcus aureus dari RS pada media VJA

(b) Koloni Staphylococcus aureus kultur laboratorium pada media VJA

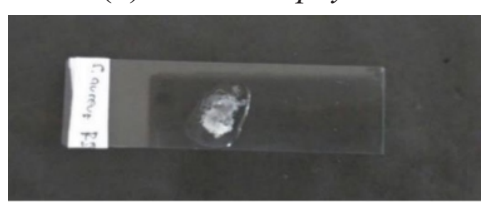

(a)

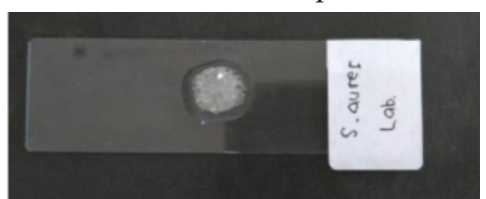

(b)

Gambar 2. (a) Uji katalase Staphylococcusaureus dari RS

(b) Uji katalase Staphylococcusaureus kultur laboratorium 


\section{HASIL DAN PEMBAHASAN}

\section{Hasil Penentuan Kadar Air Serbuk Daun Beluntas dan Meniran (Tabel 1)}

Kadar air pada serbuk Beluntas 9,9\% dan Meniran 7,5\% sehingga kedua serbuk tersebut sudah memenuhi standar untuk pembuatan ekstrak yaitu kurang dari 10\% (Emilan, 2011).

\section{Hasil Identifikasi Golongan Senyawa (Tabel 2)}

\section{Hasil Isolasi Bakteri}

Hasil isolasi dan identifikasi bakteri Staphylococcus aureus secara makroskopis pada media VJA (Vogel Johnson Agar) didapat koloni berbentuk bulat, warna koloni hitam, tepi koloni halus, permukaan koloni cembung, dan daerah sekitar koloni berwarna kuning (Todar, 2014).

\section{Hasil Identifikasi Bakteri}

a) Hasil Uji Katalase

Hasil menunjukkan bahwa terbentuk adanya gelembung. Uji katalase bertujuan untuk membedakan Streptococcus sp. (katalase negatif) dengan Staphylococcus sp. yang menghasilkan enzim katalase (katalase positif) (Todar, 2005).

b) Hasil Pengecatan Gram (Gambar 3)

Pengecatan Gram dilakukan bertujuan untuk membedakan bakteri Gram positif dan bakteri Gram negatif. Hasil pengecatan Gram Staphy-lococcus aureus berwarna ungu,bentuk bulat, susunan bergerombol, dan merupakan bakteri Gram positif.

Staphylococcus aureus merupakanbakteri
Gram positif sehingga pada pengecatan Gram akan berwarna ungu karena bakteri Gram positif mampu mempertahankan Gram A (Kristal Violet), bakteri Gram positif akan mengikat zat tersebut. Pemberian cat Gram B (iodium) akan meningkatkan afinitas pengikatan zat warna sedangkan pemeberian cat Gram C (alkohol aseton) akan melunturkan cat, hal ini karena bakteri Gram positif memiliki lapisan peptidoglikan yang tebal. Pada saat penambahan cat Gram D (safranin) tidak menyebabkan perubahan warna pada bakteri Gram positif (Supartono, 2006).

c) Hasil Uji Koagulase (Gambar 4)

Hasil menunjukkan adanya enzim koagulase. Uji koagulase bertujuan untuk mengetahui kemampuan bakteri menghasilkan enzim koagulase. Reaksi koagulase positif sangat penting untuk membedakan Staphylococcus aureus dengan spesies Staphylococcus yang lain (Cowan, 1999).

\section{Hasil Uji Sensitivitas}

Pengujian aktivitas antibakteri dengan menggunakan metode difusi. Paper disk direndam pada ekstrak dengan perbandingan 1:0, 2:1, 1:1, 1:2, dan 0:1 menggunakan konsentrai 50\% dan untuk kontrol negatif direndam pada DMSO 2\% selama 24 jam kemudian diletakkan di atas media MuellerHinton Agar yang telah diinokulasikan Staphylococcus aureus. Kontrol positif yang digunakan pada bakteri Staphylococcusaureus dari Rumah Sakit dan dari kultur Laboratorium adalah Ciprofloxacin. Perlakuan tersebut dilakukan 3 kali pengulangan.

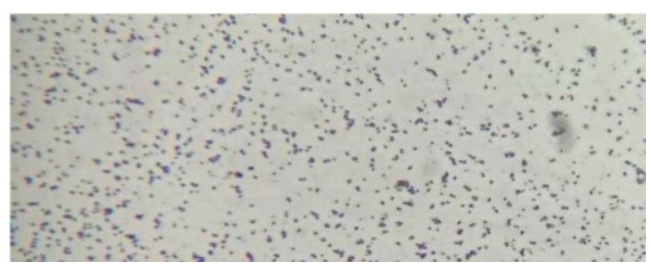

(b)

(a)

Gambar 3. (a) Mikroskopis Staphylococcus aureus dari RS

(b)Mikroskopis Staphylococcus aureus kultur laboratorium 


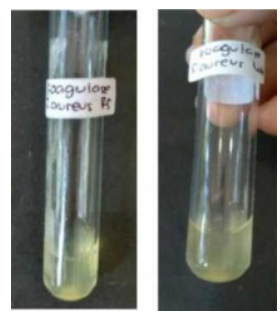

(a)

(b)

Gambar 4. (a) Uji koagulase Staphylococcus aureus dari RS

(b) Uji koagulase Staphylococcus aureus kultur laboratorium

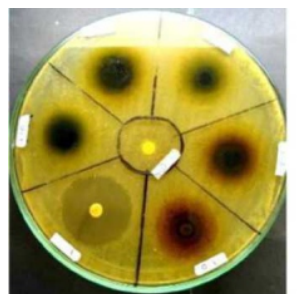

(a)

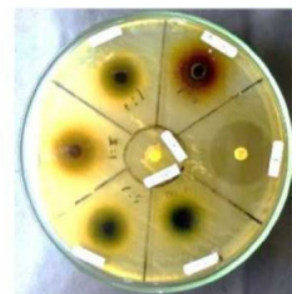

(b)

Gambar 5. (a) Uji aktivitas antibakteri Staphylococcus aureus dari RS

(b) Uji aktivitas antibakteri Staphylococcus kultur Laboratorium

Tabel 3. Hasil Uji Aktivitas Antibakteri Ekstrak Etanolik Daun Beluntas dan Meniran terhadap Bakteri Staphylococcus aureus Sampel Rumah Sakit.

\begin{tabular}{|c|c|c|c|c|c|c|}
\hline \multirow{2}{*}{\multicolumn{2}{|c|}{ Jenis }} & \multicolumn{3}{|c|}{$\begin{array}{c}\text { Diameter Zona } \\
\text { Hambat }\end{array}$} & \multirow{2}{*}{$\begin{array}{c}\text { Rata-Rata } \\
\text { Diameter Zona } \\
\text { Hambat }\end{array}$} & \multirow[t]{2}{*}{ Keterangan } \\
\hline & & R1 & $\mathbf{R 2}$ & R3 & & \\
\hline Kontrol (+) & Ciprofloxacin & 35 & 40 & 41 & 38,67 & Sangat Kuat \\
\hline Konsentrasi & $1: 0$ & 12 & 10 & 10 & 10,67 & Kuat \\
\hline $\begin{array}{l}\text { Ekstrak } \\
\text { Etanolik }\end{array}$ & $2: 1$ & 13 & 11 & 15 & 13,00 & Kuat \\
\hline Daun & $1: 1$ & 16 & 20 & 15 & 17,00 & Kuat \\
\hline $\begin{array}{l}\text { Beluntas } \\
\text { dan }\end{array}$ & $1: 2$ & 16 & 17 & 18 & 17,00 & Kuat \\
\hline Meniran & $0: 1$ & 17 & 22 & 21 & 20,00 & Sangat Kuat \\
\hline Kontrol (-) & DMSO $2 \%$ & 0 & 0 & 0 & 0 & Tidak ada daya hambat \\
\hline
\end{tabular}

Tabel 4. Hasil Uji Ekstrak Etanolik Daun Beluntas dan Meniran terhadap Staphylococcus aureus Kultur Laboratorium

\begin{tabular}{|c|c|c|c|c|c|c|}
\hline \multirow{2}{*}{\multicolumn{2}{|c|}{ Jenis }} & \multicolumn{3}{|c|}{$\begin{array}{c}\text { Diameter Zona } \\
\text { Hambat }\end{array}$} & \multirow{2}{*}{$\begin{array}{c}\text { Rata'Rata } \\
\text { Diameter Zona } \\
\text { Hambat }\end{array}$} & \multirow[t]{2}{*}{ Keterangan } \\
\hline & & R1 & $\mathbf{R 2}$ & R3 & & \\
\hline Kontrol (+) & Ciprofloxacin & 32 & 32 & 32 & 32,00 & Sangat Kuat \\
\hline Konsentrasi & $1: 0$ & 8 & 12 & 13 & 11,00 & Kuat \\
\hline $\begin{array}{l}\text { Ekstrak } \\
\text { Etanolik }\end{array}$ & $2: 1$ & 12 & 14 & 15 & 13,67 & Kuat \\
\hline Daun & $1: 1$ & 12 & 15 & 15 & 14,00 & Kuat \\
\hline $\begin{array}{l}\text { Beluntas } \\
\text { dan }\end{array}$ & $1: 2$ & 19 & 16 & 15 & 16,67 & Kuat \\
\hline Meniran & $0: 1$ & 17 & 23 & 14 & 18,00 & Kuat \\
\hline Kontrol (-) & DMSO $2 \%$ & 0 & 0 & 0 & 0 & Tidak ada daya hambat \\
\hline
\end{tabular}

Pada Gambar 6 dan 7 Grafik rerata diameter zona hambat menunjukkan bahwa diameter zona hambat ekstrak etanolik daun Beluntas dan Meniran pada perbandingan $0: 1$ yaitu ekstrak Meniran mempunyai diameter zona hambat yang paling luas diantara perbandingan yang lain yaitu $1: 0,2: 1,1: 1$, dan $1: 2$ terhadap bakteri Staphylococcus aureus sampel Rumah Sakit dan Staphylococcus aureus kultur laboratorium. Pada Gambar 8 ekstrak etanolik daun Beluntas dan Meniran mempunyai daya hambat terhadap bakteri Staphylococcus aureus sampel dari rumah sakit dan Staphylococcusaureus dari kultur laboratorium tetapi masihlebih luas diameter zona hambat yang dihasilkan oleh kontrol positif Ciprofloxacin. Hal ini dikarenakan ekstrarak etanolik daun Beluntas dan Meniran merupakan campuran senyawa yang kompleks, sedangkan Ciprofloxacin merupakan senyawa murni. 


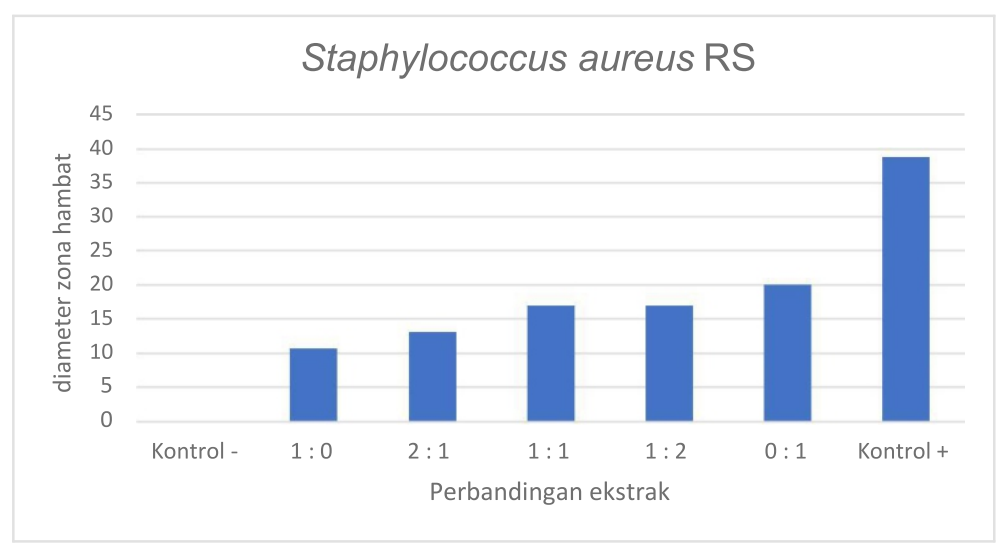

Gambar 6. Grafik rerata diameter zona hambat ekstrak etanolik daun Beluntas dan Meniran terhadap Staphylococcus aureus dari RS

Keterangan Gambar 6, 7, dan 8 :

-Kontrol - : DMSO 2\%

$-1: 0 \quad: 1$ bagian serbuk daun beluntas : 0 bagian serbuk meniran

$-2: 1 \quad: 2$ bagian serbuk beluntas $: 1$ bagian serbuk meniran

$-1: 1 \quad: 1$ bagian serbuk beluntas $: 1$ bagian serbuk meniran

$-1: 2 \quad: 1$ bagian serbuk beluntas $: 2$ bagian serbuk meniran

$-0: 1 \quad: 0$ bagian serbuk beluntas : 1 bagian serbuk meniran

-Kontrol + : Ciprofloxacin

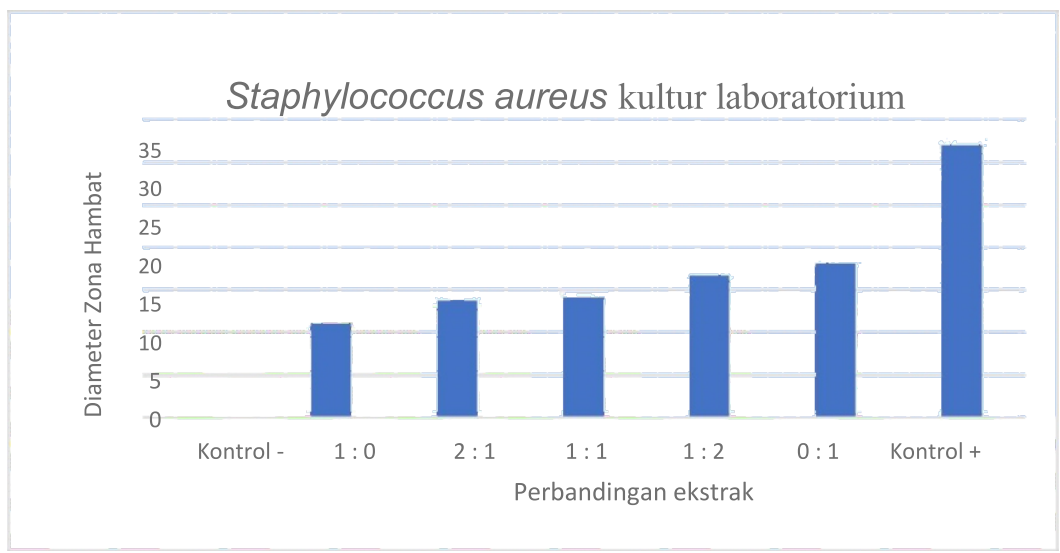

Gambar 7. Grafik rerata diameter zona hambat ekstrak etanolik daun Beluntas dan daun Meniran terhadap bakteri Staphylococcus aureus kultur Laboratorium

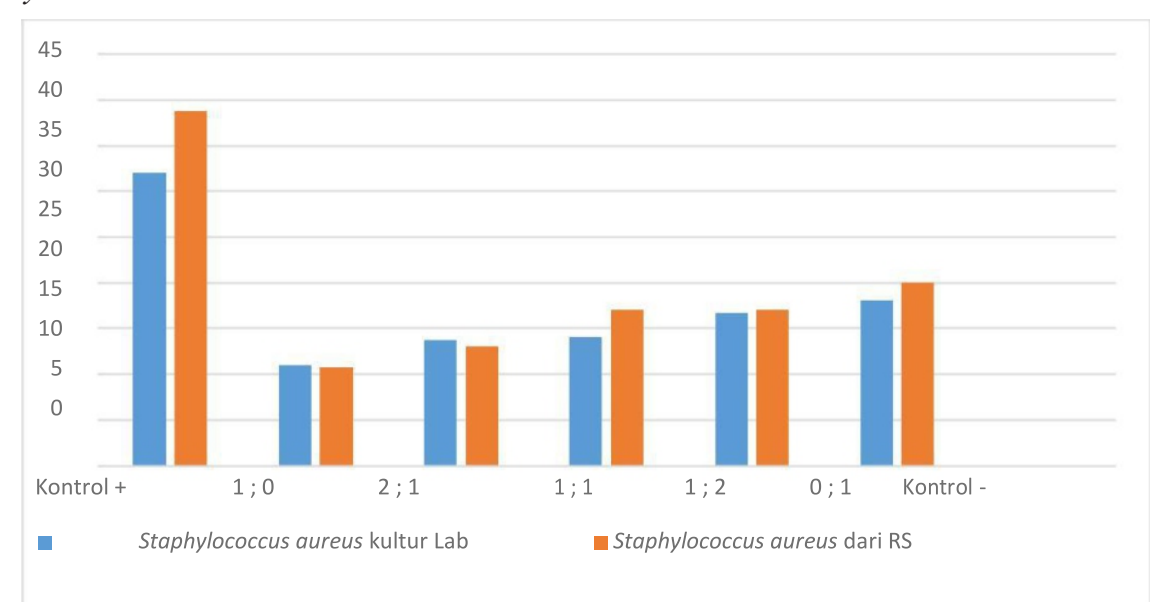

Gambar 8. Grafik perbandingan rerata diameter zona hambat Staphylococcus aureus kultur laboratorium dan dari rumah sakit terhadap ekstrak. 
Ciprofloxacin merupakan antibiotik spektrum luas yang dapat digunakan untuk bakteri Gram positif dan bakteri Gram negatif. Kontrol negative yang digunakan adalah DMSO 2\% tujuannya adalah sebagai pembanding bahwa pelarut yang digunakan sebagai pengencer tidak mempengaruhi hasil uji antibakteri ekstrak. Senyawa metabolit yang dimiliki oleh Meniran antara lain saponin, tannin, triterpenoid, alkaloid, dan flavonoid (Permadi, 2006) dan senyawa metabolit yang dimiliki Beluntas adalah alkaloid, flavonoid, tannin, minyak atsiri (Agoes, 2010).

Mekanisme kerja flavonoid sebagai antibakteri yaitu flavonoid bersifat lipofilik akan merusak membran mikroba dan senyawa flavonoid dapat tengganggu aktivitas transpeptidase peptidoglikan sehingga pembentukan dinding sel terganggu sehingga menyebabkan lisis (Fissy, 2013). Menurut Rukmana dan Mulyowati (2015) golongan senyawa flavonoid dapat menghambat pertumbuhan dari bakteri Salmonella thypi dan Streptococcus pyogenes. Senyawa saponin merupakan zat yang apabila berinteraksi dengan dinding bakteri maka dinding tersebut akan pecah atau lisis (Pratiwi, 2008). Saponin akan mengganggu tegangan permukaan dinding sel, maka saat tegangan permukaan terganggu zat antibakteri akan dapat dengan mudah masuk ke dalam sel dan akan mengganggu metabolisme hingga akhirnya terjadilah kematian bakteri (Karlina et al., 2013). Mekanisme tannin sebagai antibakteri adalah menghambat enzim reverse transkriptase dan DNA topoisomerase sehingga sel bakteri tidak dapat terbentuk (Nuria et al., 2009). Tanin dapat menghambat pertumbuhan bakteri dengan cara mengganggu transport protein, menginaktifkan adhesin sel dan menginaktifkan enzim di dalam sel bakteri (Cowan, 1994).

Mekanisme kerja alkaloid sebagai antibakteri yaitu dengan cara mengganggu komponen penyusun pepdoglikan pada sel bakteri, sehingga lapisan dinding tidak terbentuk secara uttuh sehingga menyebabkan kematian sel tersebut (Mahatmi et al., 2005).

\section{KESIMPULAN}

Berdasarkan hasil penelitian dan pembahasan dapat disimpulkan:

1. Ekstrak etanolik daun Beluntas (Pluchaea indica Less.) dan Meniran (Phyllantus nirui L.) mempunyai aktivitas antibakteri terhadap bakteri Staphylococcus aureus kultur laboratorium dan Staphylococcus aureus dari Rumah Sakit.

2. Kombinasi ekstrak etanolik (Pluchaea indica Less.) dan Meniran (Phyllanthus niruri L.) tidak memiliki efek sinergis terhadap bakteri Staphylococcus aureus.

\section{DAFTAR PUSTAKA}

Agoes, A. 2010. Tanaman Obat Indonesia. Jakarta.

Balafif, Ragaya, A., Andayani, Yayuk., dan Gunaman, E.R. 2013. Analisis Senyawa Triterpenoid dari Hasil Fraksinasi Ekstrak Air Buah Bucis (Phaseolus vulgaris Linn). Chem. Prog. 6(2): 56-61.

Cowan,M., M. 1999. Plant Product as Antimicrobial agents. Clinical Microbiolog Review, 12 (4) : 564-582.

Dalimartha,S. 1999. Atlas Tumbuhan Obat Indonesia. Jilid 1. Jakarta: Pustaka Bunda.

Djauhari,E., \& Hermani. 2004. Gulma Berkhasiat Obat. Jakarta: Penebar Swadaya.

Fissy, S.O.N. 2013. Uji Aktivitas Efektivitas Sediaan Gel Anti Jerawat Ekstrak Etanol Rimpang Jahe Merah terhadap Propioni bacterium acnes dan Staphylococcus epidermidis [Skripsi]. Pontianak: Universitas Tanjung Pura.

Green, James., Rianto, S. 2005. Pengobatan Alami Mengatasi Bakteri. Jakarta: Prestasi Pustaka.

Jawetz, E., Melnick, J. L., and Adelburg E. A. 2001. Mikrobiologi Kedokteran. Surabaya: Salemba Medika. Bagian Mikrobiologi Fakultas Kedokteran Universitas Airlangga.

Karlina, C., Ibrahim, M., dan Trimulyono, C. 2013. Aktivitas Antibakteri Ekstrak Herba Krokot (Portulaca oleracea L.) Terhadap Staphylococcus aureus dan Escherichia coli. Lentera Bio Berkala Ilmiah Biologi. 2252-3979. 2 (1): 8392.

Muhaimin, M., Liang, O.B., Ratnaningsih, E., Purwantini, E., dan Retnoningrum D.S. 2003. Optimasi proses Overproduksi, Pemurnian dan Karakterisasi protein Mga Sebagai Molekul Target Untuk Pencegahan Infeksi Oleh Streptococcuspyogenes. Jurnal Matematikan dan Sains. Vol. 8, No 3. Hal. 117-123.

Moeloek, F.A. 2005. Herbal and Traditional Medicine, National Perpectives and Policies in Indonesia. Kumpulan Kongres Nasionalke-2, Obat Tradisional Indonesia, Bandung.

Nuria, M.C., A. Faizatun., dan Sumantri. 2009. Uji Antibakteri Ekstrak Etanol Daun Jarak Pagar(Jatropa cuircas L .) terhadap Bakteri Staphylococcusaureus ATCC 25923, Escherichia coli ATCC 25922 dan Salmonella typhy ATCC 1408. Jurnal Ilmu-ilmuPertanian. 5:26-37. 
Paithankar, V.V., Raut, K.S., Charde, R.M., and Vyas, J.V. 2011. Phyllanthus niruri : Amagig Herb. Research in Pharmacy 1(4) : 1-9.

Permadi, Adi. 2006. Tanaman Obat Pelancar Air Seni. Jakarta: Penebar Swadaya.

Pratiwi, Sylvia. T. 2008. Mikrobiologi Farmasi. Jakarta: Erlangga.

Rosyidah, S. A., Nurmuhaiminina., Komari, N., dan M. D. Astuti. 2010. Aktivitas Antibakteri Fraksi Saponin dari Kulit Batang Tumbuhan Kasturi. ALCHEMY. 1 (2): 65-69.

Rukmana, RM dan Mulyowati, T. 2015. Aktivitas Antibakteri dari Ekstrak Etanolik Daun Kumis Kucing (Orthosiphon stamineus) Terhadap Bakteri Streptococcus pyogenes dan Salmonella thypi. Jurnal Biomedika. 8 (2): 15-18.

Rumanggit, Hanna M, Max RJ Runtuwene, dan Sri Sudewi. 2015. Uji Fitokimia dan Uji aktivitas Antioksidan dari Ekstrak Etanol Spons Lamello dysideaherbacea. Jurnal Ilmiah Farmasi.
Sari, F.P., dan S.M. Sari. 2011. Ekstraksi Zat Aktif Antimikroba dari Tanaman Yodium (Jatropha multifidiLinn) sebagai Bahan Baku Alternatif Antibiotik Alami. Fakultas Teknik Universitas Diponegoro Semarang.

Sastrawan, Idza N, Meiske Sangi, dan Vanda kamu. 2013. Skrining Fitokimia dan Uji Aktivitas Antioksidan Ekstrak Biji Adas (Foeniculum vulgare) Menggunakan Metode DPPH. JurnalSains 13(2): 110-115.

Setyawati, Widiastuti Agustina Eko, Sri Retno Dwi Ariani, Ashadi, BaktiMulyani, dan Cici Putri Rahmawati. 2014. Skrining Fitokimia dan Identifikasi Komponen Utama Ekstrak Metanol Kulit Durian (Durio zibethinus Murr). Varietas Petruk. Seminar NasionalKimia dan Pendidikan Kimia VI: 271-280.

Widodo, W. 2005. Tanaman Beracun Dalam Kehidupan Ternak.Malang: UMM Press. 